\title{
Introduction of environmental innovations in the Republic of Kazakhstan
}

\author{
Aigerim Kazhmuratova ${ }^{1,}{ }^{*}$, Sandigul Akhmetkaliyeva ${ }^{1}$, Aigul Boltaeva $^{1}$, Aisulu Moldabekova ${ }^{1}$ \\ ${ }^{1}$ Al-Farabi Kazakh National University, pr. al Farabi, 71, 050040 Almaty, Republic of Kazakhstan
}

\begin{abstract}
This article discusses the widespread use by countries of environmental innovations and new technologies, which will soon bring serious economic and social changes to the life of all mankind. The need for radical changes in methods and means of environmental protection, which reduce the technological impact on the biosphere of the earth, and contributing to the preservation of human health, is shown. Under the conditions of technoglobalism, the development of environmental innovations brings serious economic and social changes to the life of all mankind, the transition of national economies to a system of qualitatively safe energy and environmental development. This is due to the fact that the planning and implementation of the material progress of society often does not take into account the ecological foundations of the coexistence of society and the environment. The modern concept of quality of life covers all aspects of the interaction between man and the environment, and ecology is becoming a priority for the development of innovative economies in developed countries. In this context, Kazakhstan intends to continue to work to stimulate and encourage innovation and investment in the environmentally friendly production of goods and services, reduce greenhouse gas emissions, and apply climate-resilient technologies.
\end{abstract}

\section{Introduction}

Today, environmental innovation plays an increasingly important role for the competitiveness of national economies and companies. They open up new market opportunities in view of the growing demand for environmentally friendly products and are able to increase business performance. Environmental innovations are understood as new products, technologies, ways of organizing production, providing protection and expanded reproduction of the natural environment. Ecologically important areas of technology development include environmentally friendly biotechnologies, waste processing technologies, and low-pollution technologies. We are also talking about the integrated implementation of environmental management, environmental marketing, environmental technologies, allowing for systemic interaction between economic development and environmental protection. [1].

\footnotetext{
${ }^{*}$ Corresponding author: aigerim_k71@mail.ru
} 
Actual at the present stage is the concept of a "green" economy, which includes the ideas of many other areas in economic science, such as welfare economics, environmental economics, environmental economics and others related to sustainable development problems. These approaches seem to be interdependent, since they basically consider an economy that improves the welfare of the nation and helps reduce environmental risks, which makes it possible to establish social equality, eliminate environmental deficits, and introduce environmental innovations. The concept of "green growth" since 2008 is included in the conceptual documents and terminology of international organizations as a key term for the further development of society and individual countries [2]. In particular, at the IV session of the UN Environment Assembly, which was held in 2019 in Nairobi (Kenya), issues related to innovative solutions to environmental problems and sustainable consumption and production were discussed. Thus, states today formulate environmental policies aimed at introducing environmental innovations that contribute to the technological renewal of technologically advanced industries.

\section{Methodology}

In order to follow the principles of sustainable development, companies in many countries around the world are actively developing eco-innovations. It is "the development of any new or significantly improved products (goods or services), processes, organizational changes or marketing decisions that reduce the consumption of natural resources (including materials, energy, water and land) and reduce emissions of harmful substances throughout the life cycle "[3]. Eco-innovations stimulate the transition from a traditional (linear) economy to an environmentally sustainable, or circular, based on the principle of three $\mathrm{R}$ - Reduce, Reuse, Recycle (reduction, reuse, recycling) [4,5,6]. The circular economy implies the active introduction of environmentally friendly closed-cycle technologies and the efficient use of resources to achieve the optimal balance and harmony between the three "pillars" of sustainable development: economy, ecology and society [7]. The successful implementation of eco-innovations is facilitated by an increase in the environmental culture and responsibility of producers and consumers. According to numerous studies, the necessary conditions for the transition to a circular economy are the establishment of environmentally responsible production by companies and consideration by consumers of environmental aspects when choosing goods and services $[8,9,10,11]$.

Given the mutual interest of consumers and manufacturers in the application of ecoinnovations, certain contradictions arise from the point of view of each of the parties in obtaining and using environmental, social and economic benefits. The consumer value of eco-innovation does not necessarily guarantee an economic bonus to producers. For many consumers, the benefits of eco-innovation, both tangible and intangible, are obvious. The demand for environmentally friendly products is growing, and buyers are willing to pay more for such products [12]. To meet the "green" demand, manufacturers need to ensure the appropriate design, production, sale and recycling (recycling) of products [13]. The use of eco-products brings such benefits to consumers as reducing costs and energy consumption, improving the quality and reliability of products, expanding opportunities for its repair, modernization and disposal, reducing harmful effects on health. Aware of them, consumers stimulate companies to engage in environmentally responsible behavior [14].

The introduction of eco-innovations can reduce costs by reducing material and energy intensity, increase the efficiency and competitiveness of manufacturers, which, however, is not always obvious to them [15]. However, it is the prospect of cost optimization (in particular, for energy and materials) that most often stimulates investment in eco-innovation $[16 ; 17 ; 18 ; 19]$. It should be borne in mind that the use of only the most advanced ecoinnovations will lead to a real reduction in costs and increased productivity [20]. Thus, we 
can come to the conclusion that companies that are innovative in terms of innovation, having the corresponding potential, often create and implement eco-innovations that ultimately increase their effectiveness. When studying the impact of eco-innovations (product, process and organizational) on productivity, two categories of enterprises were compared, showing a correspondingly high or insignificant innovative activity.

For Kazakhstan, sustainable development and a green economy are not theoretical concepts, but vital issues. In Kazakhstan, there are regional and national environmental problems that require new approaches and practical solutions. Similar unresolved problems exist in many other countries that do not have sufficient experience and potential to solve them [21]. Therefore, Kazakhstan initiated the Green Bridge Interregional Program as a voluntary, regional and practical mechanism for the transition to a green economy. A green economy does not replace sustainable development goals, but is a mechanism to achieve them. The concept of a "green" economy means the conservation of nature on an economically viable basis [22]. At the same time, the main lever is the new generation of green technologies, environmental innovations and the goods and services based on them.

At the moment, the AIFC is developing tools that could help investors enter the Kazakhstani market. One of them is green bonds, which are widely used all over the world. Funds from the sale of such bonds are allocated to environmental projects.

The agency is preparing a site for the issuance of the first "green" bonds in Kazakhstan. Such bonds will be the first not only in Kazakhstan, but also, in principle, in the CIS and the Central Asian region. The rules for issuing and circulating "green" bonds on the AIFC exchange have been developed and adopted. The international rules on the so-called "green bonds principles" were taken as a basis; these are the principles of "green" bonds used by foreign developed countries. And "climate bonds taxonomy" is the systematics of "green" bonds, according to which all investors invest in these projects. These projects may also include waste management, air purification, drinking water treatment, sustainable ecosystems, etc. [22].

The global green bond market is growing annually by 40-50\%. As of January 2019, the global green bond market in the world has increased to $\$ 528.9$ billion.

The leaders in the climate bond market are China and the United States, although even in these countries such instruments are not formally positioned as climate or environmental. Climatic bonds can be of various types: securities secured by assets, corporate bonds, sovereign bonds. They can also be issued by a wide number of institutions: commercial banks, development banks, government agencies, municipal and regional authorities. China is the leader in bond issuance, while the United States has issued the largest number of green bonds. The Chinese railway corporation itself issued almost a quarter of all bonds in the world.

To improve the global environmental infrastructure, it is estimated that about $\$ 1$ trillion is needed to finance. The biggest demand for green finance, including bonds, comes from an ever-growing group of socially responsible investors. These people and organizations strive to increase their financial performance, while at the same time integrating social and environmental factors into the process of selecting areas for investment. The vast majority of such investors are in Europe and the United States. The most popular area for issuing and investing in climate bonds by a wide margin is transport, energy and multisectoral investments are in second and third place.

By 2030, Kazakhstan, in the framework of the OECD Sustainable Development Cooperation Program, along with other countries, raises the issues of modernizing the infrastructure and re-equipment of industrial enterprises, making them sustainable by increasing the efficiency of resource use and wider use of clean and environmentally friendly technologies and industrial processes involving all countries in accordance with their individual capabilities [23]. To this end, the current legislation regarding tariff setting will be 
improved and the implementation of measures to save energy and increase energy efficiency will continue through the modernization of industry, the introduction of innovative technologies, the interaction of science and production.

Kazakhstan has set goals to attract international financial flows for the greening of the economy. To finance green technologies, international funds and private investments are used, as well as republican and local budgets. Investments will be attracted through the Green Climate Fund, which was created to limit and reduce greenhouse gas emissions in developing countries, as well as to help adapt to the effects of climate change.

In addition, Kazakhstan intends to become a regional leader in the field of green finance based on the AIFC infrastructure (Astana International Financial Center) and the newly created International Center for Green Technologies and Investment Projects. AIFC will contribute to the development of green finance by providing the necessary conditions and infrastructure, stimulating the transition to a green economy and sustainable development.

The production of environmentally friendly products in Kazakhstan in value terms decreased in 2018 compared with 2014 by $4.4 \%$ and amounted to 60.9 billion tenge. The share of environmentally friendly products in the total volume of production in 2014 amounted to $0.3 \%$, in $2016-0.7 \%$ and in $2018-0.2 \%$ (see table 1).

Table 1. Production of environmentally friendly products, billion tenge, $\%$

\begin{tabular}{|l|r|r|r|r|r|}
\hline & \multicolumn{1}{|c|}{2014} & \multicolumn{1}{c|}{2015} & \multicolumn{1}{c|}{2016} & \multicolumn{1}{c|}{2017} & \multicolumn{1}{c|}{2018} \\
\hline Production in value terms & 18529,2 & 14931,4 & 19026,8 & 22790,2 & 27218,1 \\
\hline of them & & & & & \\
\hline environmentally friendly products & 63,7 & 77,5 & 127,5 & 51,6 & 60,9 \\
\hline $\begin{array}{l}\text { share of environmentally friendly } \\
\text { products in total production }\end{array}$ & 0,3 & 0,5 & 0,7 & 0,2 & 0,2 \\
\hline Source: [24] & & & & \\
\hline
\end{tabular}

It has been established that organizational eco-innovations are able to increase the effectiveness of firms, regardless of the size of their innovative potential. However, companies with high innovation activity receive additional benefits from the introduction of process innovations. The effectiveness of innovatively inactive enterprises is largely determined by their age: the positions of more mature players strengthen as experience accumulates. In turn, the productivity of companies more prone to innovation is directly related to their size - such a business can benefit from economies of scale. In general, the higher the overall innovative potential of an organization, the more often it practices ecoinnovation [25].

Despite the actualization of this problem in Kazakhstan, over the past five years in Kazakhstan, the number of enterprises with environmental innovations has remained virtually unchanged, indicating a low efficiency of investments in environmental innovations. In 2018, compared with 2014, there was a slight increase in the number of enterprises with environmental innovations by $2.4 \%$ and amounted to 253 units. against 247 units in 2014. The share of environmental innovations in the total number of innovations from 2014 to 2018 decreased from $12.7 \%$ to $7.8 \%$. The level of activity in the field of environmental innovation is measured at $0.8 \%$, the highest level this indicator reached in $2015-1.1 \%$ (see table 2). 
Table 2. The number of enterprises with environmental innovation

\begin{tabular}{|l|r|r|r|r|r|}
\hline & 2014 & \multicolumn{1}{|c|}{2015} & 2016 & 2017 & 2018 \\
\hline $\begin{array}{l}\text { Number of enterprises with environmental } \\
\text { innovations, units }\end{array}$ & 247 & 338 & 312 & 252 & 253 \\
\hline $\begin{array}{l}\text { The level of activity in the field of } \\
\text { environmental innovation, } \%\end{array}$ & 1 & 1,1 & 1 & 0,8 & 0,8 \\
\hline $\begin{array}{l}\text { The share of environmental innovations in } \\
\text { the total number of innovations, } \%\end{array}$ & 12,7 & 13,1 & 10,8 & 8,5 & 7,8 \\
\hline Source: [24]
\end{tabular}

According to the Committee on Statistics of the Ministry of National Economy of the Republic of Kazakhstan, the share of investments aimed at protecting the environment in the total investment is quite low. So, this indicator in 2014 amounted to $1.6 \%$, in $2016-0.6 \%$, in $2018-1 \%$. The highest value of the indicator, the share of investments related to the green economy was recorded in 2018 - 0.7\% (Figure 1).

An innovative economy cannot develop efficiently if an innovative product resulting from intellectual activity is not protected by a patent. Over the past five years, 1385 patents in the field of environmental protection have been granted in Kazakhstan. The largest number of patents came in 2017 and 2018 - 293 and 357, respectively.

Environmental management systems have not yet become widespread, although in sectors that are highly dependent on international markets, they are used more often. In 2016, there were 148 valid certificates in Kazakhstan (of which 133 confirmed compliance with the ISO 14001: 2004 standard and 15 - ISO 14001: 2015, which is an extremely small number given the number of regulatory objects in Kazakhstan. From 2014 to 2018. the number of patents granted for environmental technologies increased from 60 to 95 units, for energy technologies from 145 to 262 units (Figure 2)

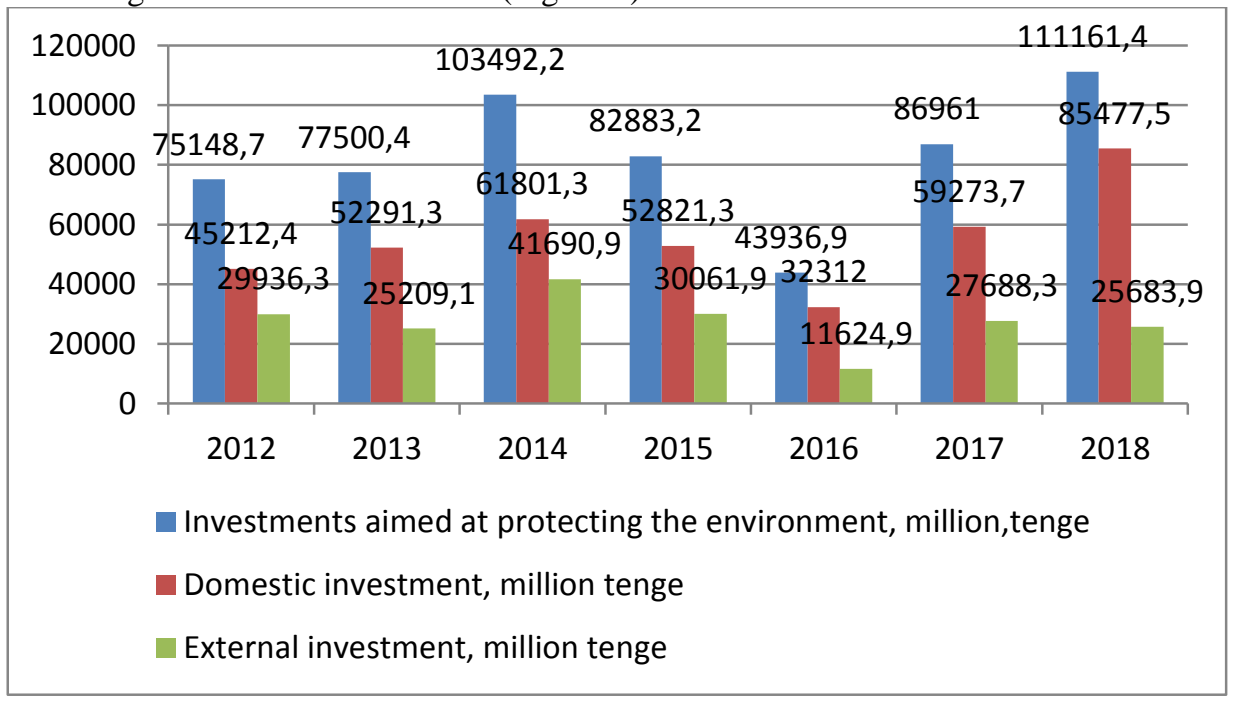

Fig 1. Investments aimed at protecting the environment, million tenge [24] 


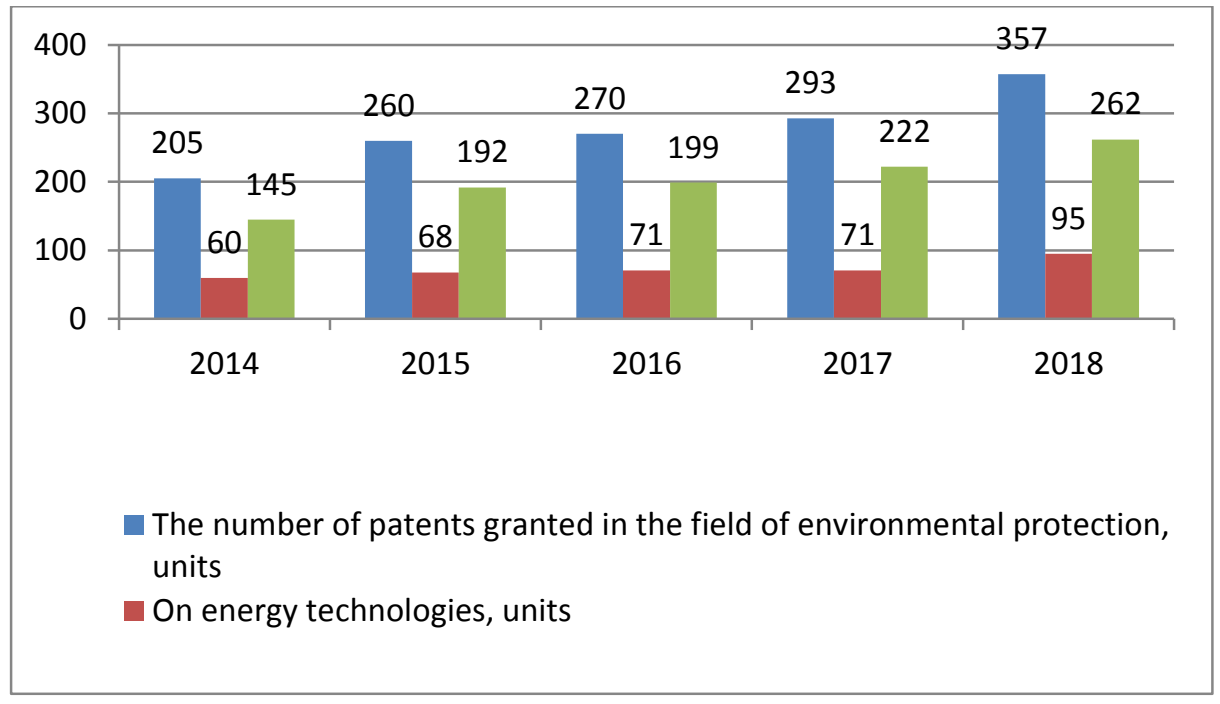

Fig 2. The number of patents granted in the field of environmental protection, units [24]

The number of issued licenses for the performance of work and the provision of services in the field of environmental protection, however, for the period from 2014-2018 decreased by $30 \%$ and in 2018 the number of issued licenses amounted to 101 units (fig. 4).

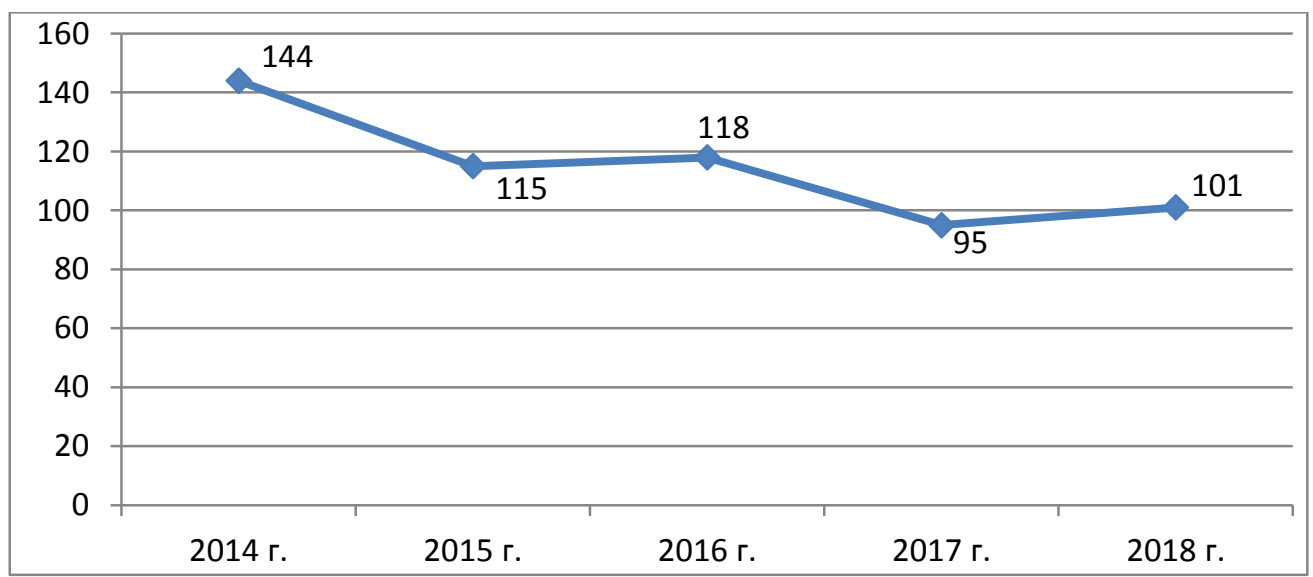

Fig.3. The number of licenses issued for work and services in the field of environmental protection, units [24]

Special environmental education arose in our country with some delay. In the mid80 s of the last century, the specialty "Environmental Protection" was introduced for engineering universities. However, the solution of numerous environmental problems required universal specialists, quite well versed in both natural science and socio-economic issues. Engineering or narrow ecological approaches for this was clearly not enough.

It became obvious that integrated environmental specialists with a managerial bias should have special training. Therefore, educational standards were developed for several undergraduate specialties: "Ecology", "Land Management", "Water Resources and Water 
Use", "Life Safety and Environmental Protection", "Forest Resources and Forestry". The content of environmental higher education is largely determined by the profile of the specialty and the university, but it necessarily includes issues of related sciences.

For the period from 2014-2018 it can be seen that there has been a reduction in the graduation of specialists from higher educational institutions in all environmental specialties, with the exception of the graduation of specialists in the specialty "Water resources and water use". In 2018, compared with 2014, there was a slight increase in graduates in the specialty "Water resources and water use" by $8.7 \%$. According to the Ministry of Education and Science of the Republic of Kazakhstan, in 2018, the graduation of environmental specialists from universities was 960 , having decreased by 1.6 times since 2014 (see table 3).

Table 3. Graduation of specialists by higher educational institutions in environmental specialties, people

\begin{tabular}{|l|l|l|l|l|l|}
\hline \multicolumn{1}{|c|}{ Name of specialties } & \multicolumn{1}{|c|}{2014} & 2015 & 2016 & 2017 & 2018 \\
\hline Ecology & 1523 & 1352 & 957 & 926 & 960 \\
\hline Life safety and environmental protection & 743 & 746 & 708 & 673 & 949 \\
\hline Water resources and water use & 276 & 271 & 217 & 282 & 300 \\
\hline Land management & 401 & 375 & 203 & 154 & 173 \\
\hline Forest Resources and Forestry & 214 & 161 & 134 & 147 & 189 \\
\hline Total specialists & 3157 & 2905 & 2219 & 2182 & 2571 \\
\hline Source: $[24]$
\end{tabular}

The share of graduates in environmental professions in the total number of graduates of higher educational institutions is insignificant and amounts to $1.97 \%$ in 2018 , showing a small percentage increase compared to 2014 ( 0.19 percentage points) (Fiure 4).

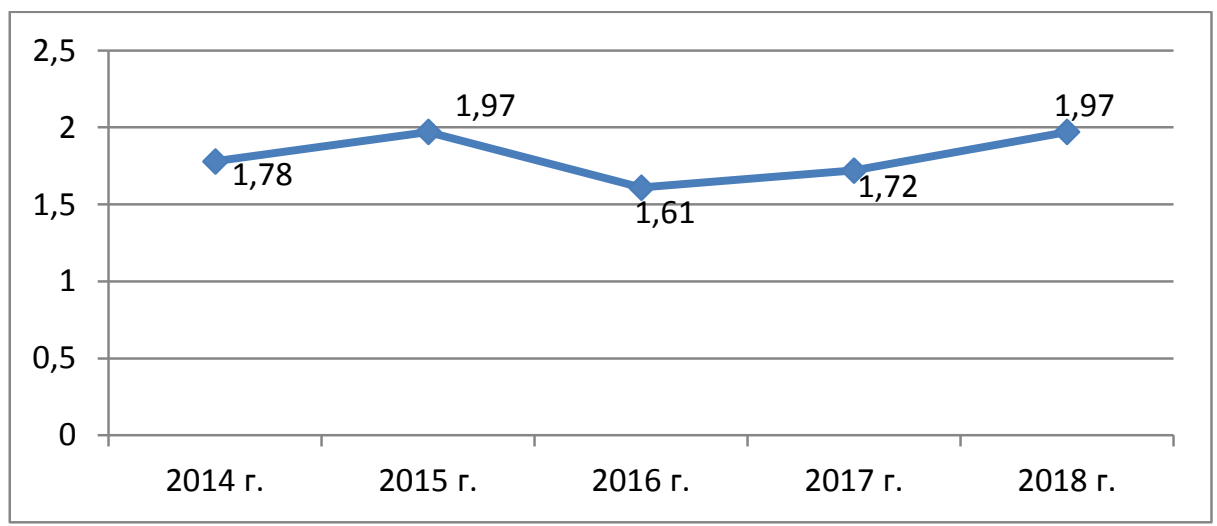

Fig.4. The share of graduates in environmental professions in the total number of graduates of higher educational institutions, \% [24]

The growing environmental problems and the economic consequences of natural and man-made disasters dictate the need for the accelerated development of certain specific areas of scientific research and technological development ("clean" energy, genomic medicine, new technologies in agriculture, environmentally friendly materials, green innovations, etc.), for many of which there are no significant backlogs in Kazakhstan. In order to meet these challenges, Kazakhstan needs to radically more deeply integrate into the global innovation 
system, increase the intensity of the implementation of scientific research, innovative business activity and the introduction of environmental innovation.

So far, we have to admit that the volume of expenditures on scientific projects related to the "green economy" over the past three years have a tendency to decrease. In the reporting period, this indicator decreased by $23 \%$ and in 2017 amounted to 84,642.8 thousand tenge. The share of expenditures on scientific projects related to the green economy to the total amount of expenditures on research and development remains unchanged in the period under review $-0.1 \%$ (table 4$)$.

Table 4. Expenses for research projects related to the green economy

\begin{tabular}{|l|c|c|c|}
\hline & 2015 & 2016 & 2017 \\
\hline $\begin{array}{l}\text { Expenses for research projects related to the "green } \\
\text { economy", thousand tenge }\end{array}$ & 109796,5 & 92433,7 & 84642,8 \\
\hline $\begin{array}{l}\text { including those related to renewable energy, } \\
\text { thousand tenge }\end{array}$ & & 2002,7 & 1832,2 \\
\hline $\begin{array}{l}\text { The share of expenditures on scientific projects } \\
\text { related to the "green economy" to the total amount } \\
\text { of expenditures on R\&D,\% }\end{array}$ & 0,1 & 0,1 & 0,1 \\
\hline Source: [24] & & \\
\hline
\end{tabular}

The formation of environmental culture involves providing the basics of environmental knowledge in the education system and a wide environmental and educational work for different categories of the population. The success of this task is determined by the active position of civil society, the interest and personal participation of representatives of the general population. This implies the development of a broad environmental movement that encompasses not only environmentalists, but also representatives of all sectors of civil society.

In Kazakhstan, the number of programs / projects in the field of environmental awareness and enlightenment at the regional and national level over the past two years has tended to decrease. In 2017, 2018, their number was 24 units. and 26 units. respectively. The greatest growth was recorded in 2016 - 84 programs / projects in the field of environmental understanding and enlightenment (Figure 5).

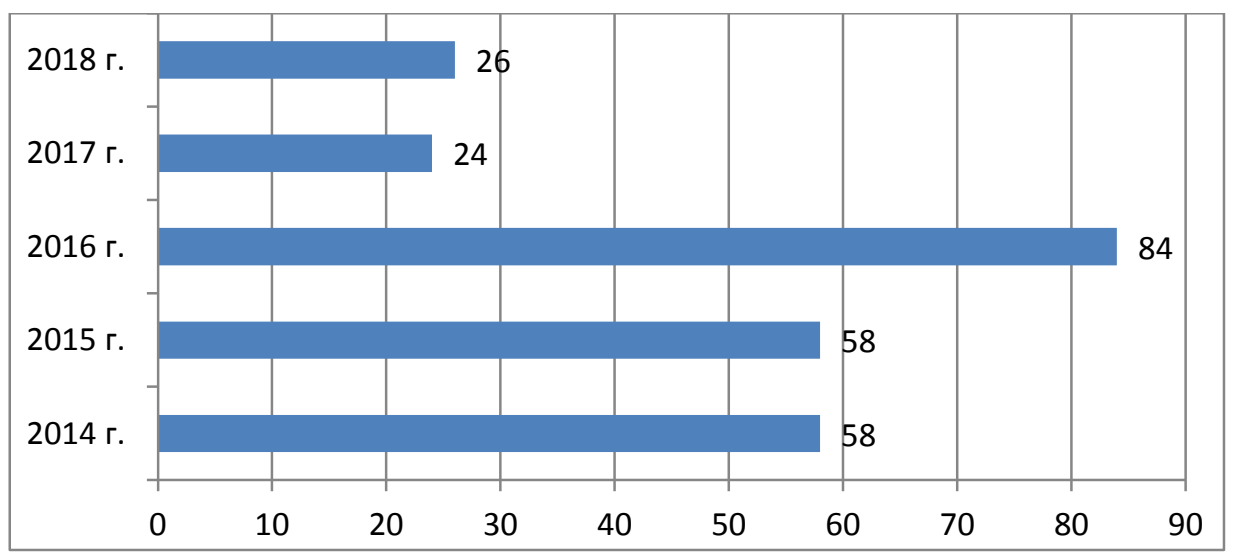

Fig.5. The number of programs / projects in the field of environmental understanding and enlightenment at the regional and national level, units [24] 
There are many examples of how governments, organizations and universities create special funds to provide companies with grants for innovation and environmental sustainability initiatives. These funds are aimed at financing various initiatives, from research and development to new technologies and related activities. National and regional grants may also be allocated for testing and market launch. In many cases, priority is given to SMEs in obtaining grants $[26,27]$.

In countries such as Korea, Brazil, India, China, and South Africa, government programs focus on research and development of eco-innovative knowledge and technology. In Malaysia, the Philippines, Mexico, Canada, Denmark, the United Kingdom, Japan, Australia, New Zealand, the USA, Israel, and Thailand, there are government funding programs that help SMEs implement environmental sustainability and innovation projects. Under these programs, SMEs can receive advice and support, as well as grants that cover up to $70 \%$ of their project costs. For example, in Malaysia, the National Council for the Development of SMEs (NSDC) recently adopted, as part of its master plan for SMEs, the decision to allocate special funding for inclusive innovative initiatives implemented by SMEs with incomes below $40 \%$. There are government funding programs that help SMEs implement environmental sustainability and innovation projects. Under these programs, SMEs can receive advice and support, as well as grants that cover up to $70 \%$ of their project costs. For example, in Malaysia, the National Council for SME Development (NSDC) recently adopted, as part of its master plan for SMEs, the decision to allocate special funding for inclusive innovative initiatives implemented by SMEs with incomes below 40\% [27].

The study and wider use in the Republic of Kazakhstan of foreign experience in environmental regulation and support will increase the effectiveness of state environmental policy, reduce the level of adverse environmental impact and will help the republic move along the path of sustainable development.

\section{Conclusions}

For the republic, the environmental focus of economic development today is especially important against the background of a general inefficiency in the use of natural resources and low energy conservation. The innovation development strategy of Kazakhstan provides for alternative technologies (hydrogen energy, green technology, the use of wind, solar, tides and other renewable energy sources) to achieve economically acceptable parameters; Improving the environmental parameters of thermal energy, primarily coal.

The tasks of integrating the country into the world economic system and joining the club of developed OECD countries require, first of all, improving the legislative and institutional framework for the transition to a green economy, and a strategic planning system.

According to strategic documents, the main result of Kazakhstan's policy in the field of "green" economy and environmental protection will be an increase in the quality of life of the population, environmental safety, reduction of environmental risks and ecological deficits, sustainable development and increased competitiveness.

\section{References}

1. Mukhtarova, K., Ziyadin, S., Kupeshova, S. \& Doszhan, R. (2017). Problems of developing the foundations of sustainable competitiveness of industrial and innovative economy in Kazakhstan. Economic Annals-XXI, 168(11-12), 38-43

2. Ziyadin, S., Malayev, K., Yessenova, G., Beyzhanova, A. (2019) Oil and gas companies in the innovation conditions of economic development in Kazakhstan. /E3S Web of Conferences 2019-135,04025European Commission, p. 8, 2012 
3. Tleppayev, A., Tovma, N., \& Zeinolla, S. Construction of Kazakhstan's system of energy efficiency indicators for the development of industrial competitiveness. In Vision 2020: Innovation Management, Development Sustainability, and Competitive Economic Growth (pp. 2071-2079) (2016)

4. Su B., Heshmati A., Geng Y., Yu X. Journal of Cleaner Production. Vol. 42. P. 215-277 (2013)

5. Ghisellini P., Cialani C., Ulgiati S. Journal of Cleaner Production. Vol. 114. P. 11-32. DOI: 10.1016/j.jclepro.(2016)

6. Agan Y., Acar M.F., Borodin A. Journal of Cleaner Production. Vol. 51. P. 23-33(2013). DOI: $10.1016 /$ j.jclepro.2012.12.043

7. Hojnik J., Ruzzier M. Environmental Innovation and SocietalTransitions. Vol. 19. P. 3141 (2016). DOI: http://dx.doi.org/10.1016/j.eist.2015.09.006

8. Horbach J., Rammer C., Rennings K. Ecological Economics. Vol. 78. P. 112-122 (2012). DOI: $10.1016 /$ j.ecolecon.2012.04.005

9. Li Y. Journal of Cleaner Production. Vol. 66. P. 450-458 (2014) DOI: 10.1016/j.jclepro.2013.11.044

10. Ziyadin, S., Beyzhanova, A., Orazymbetova, A., Yessenzhigitova, R. Proceedings of the 32nd IBIMA c. 3080-3084 (2018).

11. Sarkar A.N. International Journalof Ecology and Development. Vol. 25. № 2. P. 71-104, (2013)

12. Kammerer D. Ecological Economics. Vol. 68. № 8-9. P. 2285-2295 (2009). DOI: 10.1016/j.ecolecon.2009.02.016.

13. EASAC Circular economy: A commentary from the perspectives of the natural and social sciences. Brussels: European Academies' Science Advisory Council (2015)

14. Belin J., Horbach J., Oltra V. GREThA Discussion Paper 2011-17. Bordeaux: Université Montesquieu Bordeaux IV. Режим доступа: http://ideas.repec.org/p/grt/wpegrt/201117.html, дата обращения 26.06.2013 (2011)

15. Govindan K., Diabat A. Madan Shankar K. Journal of Cleaner Production. Vol. 96. № 1. P. 182-193 (2014) DOI: 10.1016/j.jclepro.2014.02.054

16. Horbach J. Research Policy. Vol. 37. № 1. P. 163-173 (2008). DOI: 10.1016/j.respol.2007.08.006.

17. Montabon F., Sroufe R., Narasimhan R. Journal of Operations Management. Vol. 25. № 5. P. 998-1014 (2007). DOI: 10.1016/j.jom.2006.10.003.

18. Kesidou E., Demirel P. Research Policy. Vol. 41. № 5. P. 862-870.DOI: 10.1016/j.respol.2012.01.005.

19. Onaltayev, D., Kazhmuratova, A. Akhmetkaliyeva, S., Malikova, R., Yelyubayeva, A. E3S Web of Conferences 2019

20. Ziyadin, S., Streltsova, E., Borodin, A., Kiseleva, N., Yakovenko, I., \& Baimukhanbetova, E. Sustainability, 11(9), 2544. (2019). DOI: 10.3390/su11092544

21. Mutanov, G., Ziyadin, S. / E3S Web of Conferences, DOI: $10.1051 /$ e3sconf/201913504056 (2019)

22. Stat date https://stat.gov.kz/edition/publication/month

23. Hojnik J., Ruzzier M., Manolova T. Eco-Innovation and Firm Efficiency: Empirical Evidence from Slovenia. Foresight and STI Governance, vol. 11, no 3, pp. 103-111 (2017) DOI: 10.17323/2500-2597.2017.3.103.111

24. Yedilbayev, B., Kozhamkulova, Z., Abdikul, S., Tulebayeva, N. New models of road transport system E3S Web of Conferences 2019 
25. Kozhakhmetova, A., Zhidebekkyzy, A., Turginbayeva, A., \& Akhmetova, Z. Modelling of project success factors: A cross-cultural comparison. Economics \&; Sociology, 12(2), 219-234 (2019)

26. SME Corp, Malaysia www.smecorp.gov.m

27. Beyzhanova, A., Mamyrbekov, A., Umarov, I., Orazymbetova, A., Khairullaeva, A. Impact of digital marketing development on entrepreneurship. E3S Web of Conferences 2019 